\title{
Second Language Acquisition in Arab Learners: A Paradigm Shift
}

\author{
Mohammed Ilyas Ebrahim and Naeem Afzal
}

\begin{abstract}
The Arab world has witnessed a very positive and drastic change in the use of English language both in business and education. This change is significant in many ways including a society more inclined to literacy, as well as a keenness to learn and command the English language. However, in universities and other higher educational institutions a peculiar feature of the Arab EFL learners is that they cannot understand the oral as well as written English language even when articulated normally. It has also been observed that still a few of them "prefer" the use of L1 i.e., Arabic, in acquiring the English language (L2) for diverse reasons including not fully skilled and trained in this language or often lacking motivation to communicate in $\mathbf{L}$.

This research study contextualizes and analyses the issues usually raised in Second Language Acquisition in the Arab learners' situation. The paper also briefly refers to the critical debate over recognizing what is being called as Arabicized English. This paper also refers to a few theoretical and ideological perspectives drawn from Krashen's Input hypothesis theory and Chomsky's linguistics theory which is based on the belief that language learning is a result of a continuum that happens between the "internal reality" of language in the individual's mind and the "external reality" of language in society.
\end{abstract}

Index Terms-Arab learners, EFL classrooms, first language (L1), second Language (L2).

\section{INTRODUCTION}

Over last few decades, the Arab learners have shown a keen interest in recognizing the English language as a language of common usage in business and in education, a phenomenon much supported by the Saudi government [1]. Many universities in Saudi Arabia have introduced courses in English language and literature. Students too have shown great interest in acquiring the knowledge of this language. But, despite this wide popularity and demand of English language, and a rigorous program run by the government and educational institutions, English language has not been in wide use. There are several challenges and issues that have been identified by many researchers and academicians among which include the inadequate teaching curricula, teaching methodology, lack of skilled teachers and so on [2]-[4] or even lack of motivation [5], [6]. This has so far unfortunately prevented the Arab learners to have a complete input in learning the English language (L2).

The authors are Faculty members in a Saudi university.

Manscript received April 11, 2015; revised September 12, 2015

The authors are with Department of English, Prince Sattam Abdul Aziz University, Saudi Arabia (e-mail: m.ebrahim@psau.edu.sa, n.awan@psau.edu.sa).
This research study is based on their first hand experience of teaching the Saudi students. The authors carried out this research study considering various pedagogical as well as cultural issues and come to the conclusion that these issues must be addressed by making English (L2) more popular in their EFL classrooms.

The main objective of this research was to teach a language or literature course to a group of non-natives focusing upon learning objectives as well as enhancing the learning outcomes. This was the key variable in designing this study and it led the authors to propose the following research question: "Despite all kinds of pedagogical issues and use of Arabic language in EFL as reported, what else can be done to create a paradigm shift that can lead to a more effective learning of English for Saudi students?" Such a thought of a paradigm shift further led the authors to another question whether there could exist a specific "Arab" way of acquiring the learning of a second language. The authors had also come across a term called "Arabicised" English, resulting from "a process of being nativised" to be an authentic representation of social and cultural values [7]. This research paper is an outcome of such innovative thinking.

It was more important for the authors to find out what strategies can be devised that would directly address these research questions. The first requirement was to contextualize the issue of allegedly using the L1 (i.e Arabic language) in the classroom by the teachers as well as by students in order to acquire English (L2). [8]-[11]. For this purpose, the authors made a deep study of Krashen's Input Hypotheses theory [12] as well as Chomsky's claim that linguistics "is based on the internal reality of language in the individual mind rather than on the external reality of language in society" [13]. Both these theories are relevant in this context as they refer to a paradigm shift that can be offered by a non-native teacher in an EFL environment. Last, but not the least, this was also kept in mind that the mother tongue or the first language (L1) always facilitates the process of the second language acquisition.

The primary objective of this research paper was therefore to review problems being faced by Arab EFL learners and also seek remedial measures to resolve these problems. The study is thoroughly based on a few premises that in Saudi Arabia English has so far not assumed the role of a Target Language (TL) as many of its native speakers are not exposed to it; Second, English is not the native language of the Arab EFL learners; thirdly a few of them still reportedly prefer to use Arabic (L1) in EFL classrooms instead of English (an issue most common in any L2 learning situation and commonly refereed as mother tongue interference); Fourth, Arab learners employ Arabic as their "formal language" in business and communication; and finally, absence of 
appropriate learning inputs in their language teaching context which can be for many reasons like inappropriate English language curriculum or unavailability of EFL qualified teachers.

\section{KRASHEN'S INPUT HYPOTHESES}

In 1980s Steven Krashen propounded the most widely accepted second language acquisition theory that helps us to understand the nitty-gritty of a foreign language acquisition. Krashen (1982) carries forward Input Hypothesis theory into four perspectives: the Acquisition-Learning perspective; Natural Order perspective; Monitor perspective; and the Affective Filter perspective. Each perspective lays out a hypothesis to be judged in a given situation [12].

The Acquisition-Learning perspective highlights two methods to develop an ability to use a second language (L2). The first, as Krashen lays it, is through acquisition process, a "subconscious process closely related to first language learning". Second, Krashen shows how a kind of learning is acquired through "a conscious process that leads to knowing about language". As an example, Krashen shows how students are actually learning about language when they are learning to apply grammatical rules. In other words Krashen recommends to giving more priority language acquisition in a macro way rather than learning language just to acquire a so-called second language competence. Hence, if Arabic (L1) interferes in the learning of English (L2) in Arab classrooms, it is just a subconscious activity rather than a conscious effort to give priority to $\mathrm{L} 1$ over L2.

Secondly, the Natural Order perspective highlights the concept of "language rules" being acquired in a sequence and that they are predictable. Therefore, some rules in language acquisition "precede" others. In other words, Krashen says that "language acquisition happens not as a result of learning about grammatical structures, but occurs naturally, in a progressive, logical order, as does the first language learning". Thus it can be safely assumed that if EFL teachers adopt a natural order in the learning of English (L2) by using English itself in Arab classrooms, it might be a better alternative rather than blaming the mother tongue interference of Arabic (L1).

Thirdly, Krashen advances his Monitor perspective which clarifies that "second language production happens as a result of the learners' subconscious knowledge and acquired competence at any stage of learning". In this process, the conscious knowledge monitors or edits whatever is acquired. However, Krashen sets two conditions for monitoring that: "the performer must be consciously concerned about correctness" and second, "he or she must know the rule". The EFL teacher can predict one benefit in this perspective, that is, if the learner gives much attention to "form", it can result in an increase in "grammatical accuracy"; however, there is always a fear that "communication is often compromised when language use is overly monitored or edited by the one producing the language."

In The Affective Filter perspective, Krashen points out that there is "...a mental block that prevents acquirers from fully utilizing the comprehensible input they receive for language acquisition". This means that the learner who is "comfortable in the learning environment and motivated to learn the target language faces a low affective filter". According to Krashen, this is an outcome of "low anxiety environment" in which the L2 is acquired. On the other hand, students who lack motivation or feel undue anxiety and vulnerability to acquire the "target language" in their learning environment often experience a high "affective filter". This impedes the language acquisition process.

One can think of applying Krashen's principles in both teaching and evaluation of English (L2) in a classroom situation. In a learning situation, the EFL teacher interprets the learners' responses and analyses them in one of the Krashen's theoretical perspectives. It then becomes much easier to teach any target language.

\section{CHOMSKY THEORY OF L2 ACQUISITION}

Chomsky (1995) has quite different views on Second Language Acquisition. His theory constitutes three basic principles: one, it is important to know "what constitutes knowledge of a language" second, "how knowledge of language is acquired" and third, "how knowledge of language is put to use" [13]. All his contentions about knowledge of language are applicable to L2 as well. Let us examine these principles in the context of our study.

Firstly, according to Chomsky, the primary purpose of linguistics acquisition should be to unravel the "language contents of the human mind"; in other words, to know "what native speakers know about language -- their linguistic competence" If this primary purpose is achieved, it becomes easier to produce "a fully explicit representation of the speaker's competence", for instance, a generative grammar of a 'particular language', L2 in this context. Language, according to Chomsky, therefore, is based on the "internal reality of language in the individual mind rather than on the external reality of language in society".

A second goal for linguistics, according to Chomsky, is to discover how the human mind can acquire linguistic competence. Chomsky recommends a very simple method to achieve this goal. He recommends to following a child when the "innate principles" of his mind create linguistic competence, or the child's mind utilizes the "language input" by using its built-in capabilities.

Finally, to know how knowledge of language can be put to use, Chomsky answers that this knowledge can be used in many ways - for day-to-day communication, for business, for soil conservation, for banking and commercial enterprises, for translation, some of these are true of the Arab world.

\section{A PARADIGM SHIFT}

As said earlier, many universities in Saudi Arabia and other agencies including the Ministry of Education, have shown keen interest in providing opportunities of learning the English language, a change that can be called a paradigm shift. This distinctive situation is seen as a result of the economic and political interdependence between the Arab countries and the other nations of the world, which necessitated the Arab countries to acquire a linguistic access to the Western World 
in order to enter into business alliances with most of the English speaking countries. Several forces are working towards achieving this paradigm shift.

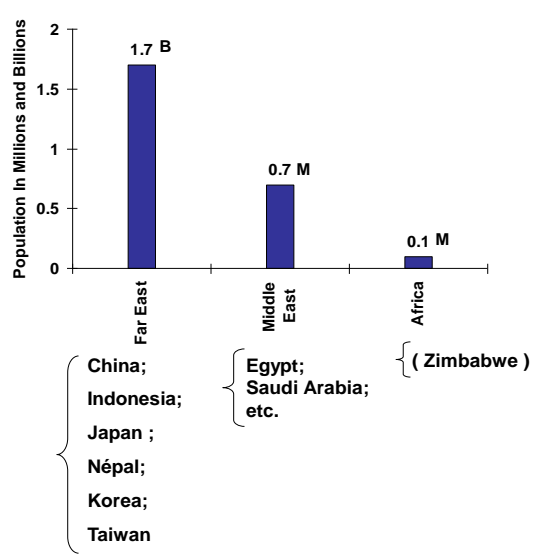

Fig. 1. Regions of the world where English is L2.

The graph above (Fig. 1) which is taken from Kachru (1988) is a visual inference in support of the rising usage of English as L2 [14]. The numbers on the graph reveal that the Arab world is second in place among regions where English is used as L2.

This position has been achieved due to a lot of admiration that the Arabs have for the English language and want it to be a language of communication too. Besides Kachru, various other scholars including Al Hajailan (2003), Crystal (2003), Elyas, T. \& Picard, M. (2010) and Rahman (2011) have also acknowledged the growing status of the English language in the Arab region [15]-[18].

During this research study, the authors entered into several formal and informal discussions with the Arab students, to understand the manner they learnt English in the past at secondary and tertiary levels and also to understand their expectations from teachers and the curriculum that they now study at university level. We wish to record a few of their comments here which really supported the idea of a paradigm shift taking place in learning English language (L2) in Saudi Arabia. We found out that students were really direct and forward in acquiring the second language (English) and gave away various reasons - to see themselves in a nice profession, business growth and foreign travel; being competitive by nature, most of them like to be tested and want teachers to correct every mistake that they would make when they speak or write.

They also shared that they were aware of the plight of most teachers who have accepted the challenge to teach in the Arab world and they appreciate this gesture. They don't mind to have teacher-centered classes instead of learner-centered, although they preferred the latter. It was very motivating to learn about their thoughts that have really paved the way of this much discussed paradigm shift in this geographical location and also encouraged the authors to take upon the current study.

\section{LITERATURE REVIEW}

Several researchers have investigated problems that have been encountered by EFL learners in Saudi Arabia including
M.A. Alam, S.M. Hussein and B.A. Khan (1988), Naomi Bolotin (1996), Rabab'ah (2003), Sultan, Al- H. (2003) and Liton, H. A. (2012). They have discussed diverse problems ranging from L1 interference in classrooms to cultural, educational, political and personal inhibitions of Saudi learners that have led to serious issues and delays in the acquisition of the English language [19]-[23].

During the pilot study of this project and also while pursuing the research work already done in this field, a significant issue that emerged was the use of Arabic (L1) in most classrooms including the EFL classrooms. Many researchers studies have discussed in detail the issue of using the Arabic language in EFL classrooms. A. Al-Abdan (1993), N. N. Kharma (1994), H. Al-Nofaie (2010) and Alshammari, M. M. (2011) [8]-[11]. All these studies unanimously agree that students give priority to L1 in EFL classrooms because they fail to "express their ideas in second language (L2)". Nation (2003), likewise, in an explorative study on Arab learners, attempts to "justify" the use of first language i.e Arabic [24]. According to him, "learners tend to apply L1 either because of their shyness, lack of proficiency, or being unmotivated to communicate in L2".

\section{RESEARCH METhodology}

This research was carried out using the experimental method of research. The Experimental Research method was found to be appropriate for this type of study because a proof is always available if a certain variable affects other variables e.g.--one can find out whether L2 (independent variable) gets affected and has different results when taught through a specific teaching method like audio visual, lecture method, direct method or when teaching different courses like grammar, vocabulary or skills (dependent variables). Thus the effect of substituting one teaching method or one course (dependent variable) in whole or in part for another makes the difference in the desired output. Every effort was made to maintain our control over the variables under study and the deliberate manipulation of each of them in questionnaires and during pre/post tests and pilot study was made in order to study its effects.

The author was aware that in experimental research, it is necessary to acquire facts first hand (data) direct from the source (learners) and then actively process the data to stimulate the production of desired information. This study started with a few working hypotheses about L2 acquisition among the Arab learners along with probable results as were indicated from the available critical studies and other prior research. The purpose of this study was to get enough facts (data) to prove or disprove the hypotheses. Hence questionnaire and other tests/feedback surveys (research design) were set up adequately and accordingly.

The research instruments that were used for the data collection included a pilot study, two tests (pre- test and post-test) comprising L2 components like grammar, vocabulary, composition etc and a few questionnaires. The pilot study consisted of a few questionnaires. At the end, we made a final test to see the effectiveness of the suggested teaching method with an attitude cum feedback questionnaire for the students. The pre-test helped the authors to measure 
the students' performance before using the suggested techniques, and the post-test helped to see their effectiveness. The attitude-cum-feedback questionnaire was prepared in order to know the students reaction for the suggested techniques and also the impact on their learning. The data was analyzed by descriptive statistics using the SPSS software.

The sample consisted of two groups of learners: one was an experimental group and the other was a control group of 20 students each on which we performed our experimental procedure including administering questionnaires, interview schedules, group discussions, including asking them to narrate their experiences of the L2 classrooms. These groups were chosen through cluster sampling method from the penultimate year of 4-year degree program. These students had reached a level by which they were supposed to have got considerable amount of L2 learning. When the preliminary survey for this study was started, it was found that many learners were really unmotivated and completely uninterested in learning. Fortunately, a few students who were good and keen to learn finally agreed to participate in this experiment. So the two groups were formed.

These were the model groups throughout the course of this study. Data was collected by recording results obtained from tests and questionnaires given to control and experimental groups.

\section{RESULTS AND FINDINGS}

Only the experimental group was exposed to the independent variable and was kept informed about the observations and findings of questionnaires and observations. This group contributed greatly in taking forward the understanding of issues raised in this study. However, the other group, the control group was kept separate from the rest of the experiment and no results or findings were shared with this group though they did participate in all tests, questionnaires and surveys along with the first group.

The authors were very careful in designing the experiments and constructing the pre/post tests and questionnaires. It was a kind of controlled experiment where the change or impact would be seen only on one variable i.e the independent variable, which in this experiment, was teaching English as a second language. The independent variable (L2) was divided into different parts or what we called nodes as each node would interact with a dependent variable. For instance, to find why Arabic (L1) was used in EFL classrooms or whether teachers use appropriate teaching methods to teach $\mathrm{L} 2$ or whether students sustain motivation level to learn the L2 were a few of the nodes of the independent variable (L2).

The experimental group got all of the circumstances of each experiment related to the independent variable (test, questionnaire etc.) and also the target dependent variable being tested in a particular experiment. The control group, however, was only exposed to the objectives and the content of the tests but did not know what was being tested nor about the results. For instance, in the pre-test, we asked both groups to write a paragraph on a given topic. The experimental group was provided with some learning aids like vocabulary items and a paragraph outline while the control group was not provided any learning aids. The idea was to determine whether any type of learning aids really helped a learner in the L2 situation. In such an experiment, the purpose of the control group was only to provide a back up platform and also an opportunity to compare when at the time of analyzing results.

For example, in the above experiment, the results showed that the experimental group which had an access to learning aids was creative enough and succeeded in writing a nice paragraph while the control group though did make an effort to write a paragraph but we could see the difference in their quality of writing which was due to learning aids provided to one group and not to the other.

Another example that can be cited from our experiment was the use of past form of verbs. Most Arab learners never knew that the past form of 'eat' is 'ate' or 'bring' is 'brought'. This lack of information forced them to use present forms of verbs even to describe a past event. In the beginning of our experiment, we tried to teach students the past forms of verbs and often corrected them when they committed mistakes in order to make them conscious about it. But it didn't work out much even after providing the list of all three forms of verb. A few of them enjoyed the rhyming in three forms like "sing -sang-sung" or were amazed to see all three forms same of verbs like cut, cost, hurt, put, shut, spread etc which was not much motivating to the authors as the desired change was still far off. It was becoming a big challenge until we decided to teach tenses, not in the conventional way but through 'Direct and Indirect speech' but only to the experimental group. The group showed interest as they were quite comfortable in learning how to report a speech or a dialogue. We asked them to narrate in their own words any conversations that they had with the friends or family members. Surprisingly, their use of past forms "improved" a lot in the post-tests. But the other group who had not practiced Direct and Indirect Speech did not show any sign of improvement.

To cope up with such issues, the authors recommended the use of Direct Method of teaching in place of Grammar-Translation Method since the former required a learner to be absorbed in L2 acquisition in the same way as he would learn the first language (L1). The reason was simple, The Direct Method used inductive methods to teach grammar as well as listening and speaking and focused only on "useful everyday" language.

Our experiments also revealed that although teaching L2 is tough task in the given circumstances, but if done in a creative and innovative manner, students not only enjoy learning but they are also able to understand the language and communicate their ideas as well very effectively. The authors also realized that it was really important to give students the opportunity to become autonomous. Of course they would have difficulty at first, considering the difference between the English and the Arabic scripts, and also the risk of distancing themselves from their L1, that is Arabic, but by providing the 'easy' solution in the form of learning aids or trained instructors or well structured text books or creative and innovative teaching techniques, they would never think of any distance being created between their first language and a foreign language while in the class.. The researchers could elicit such things in the attitude surveys, groups tasks and feedbacks at the end of the experiment. It was learnt that learners felt autonomous and independent in making a 
collaborative work.

\section{CONCLUSION}

In the light of these research findings and expert references, one can safely assume that the learning of L2 contextually in the Arab world aims at only to understand a "new language" to be acquired along with Arabic; however, the authors felt that learners would not discriminate between a "second language" and "a foreign language" learning in a classroom. There are quite a few issues and challenges that must be addressed and one of them is to reduce the use of Arabic in EFL classrooms. Only then, the English language can co-exist with Arabic in the mainstream as in the case of many European languages where English co-exists as L2 along with the national language or L1.

The paradigm shift that we started this research paper in the context of Saudi Arabia is not very far as one can see its signs visible in multifarious ways. Many Saudi universities have full-fledged English Departments with skilled EFL instructors who are incessantly striving hard to achieve a paradigm shift in integrating the use of English (L2) in both business and education sectors.

\section{REFERENCES}

[1] British council. [Online]. Available: http://englishagenda.britishcouncil.org/consultancy/ourtrackrecord/en glishworkandstudyprojectsaudiarabia

[2] I. A. Khan, "Challenges of teaching/learning English and Management," Global Journal of Human Social Science, vol. 11, issue 8, November 2011

[3] M. M. U. Rahman and E. Alhaisoni, "Teaching English in Saudi Arabia: Prospects and challenges," Academic Research International, vol. 4, no. 1, January 2013.

[4] F. Shehdeh. (2011). Challenges of teaching English in the Arab world: Why can't EFL programs deliver as expected? [Online]. Available: http://ipac.kacst.edu.sa/eDoc/2011/195630_1.pdf

[5] A. L. Hussain, "Developing EFL teaching and learning practices in Saudi Colleges: A review," International Journal of Instruction, vol. 5 , no. 2, July 2012.

[6] Y. A. N Al-Shumaimeri, "A study of classroom exposure to oral pedagogic tasks in relation to the motivation and performance of Saudi secondary learners of English in a context of potential curriculum reform," Unpublished Ph.D. Thesis, University of Leeds, Leeds, 2003

[7] A. Mahboob and T. Elyas, "English in the Kingdom of Saudi Arabia," World Englishes, vol. 33, no. 1, pp. 128-142, 2014.

[8] A. Al-Abdan, "A study on using Arabic in teaching English in Saudi intermediate schools," King Saud University Magazine, vol. 50, no. 2, pp. 396-426, 1993.

[9] N. N. Kharma, "Use of the mother tongue in the ESL classroom," IRAL, vol. 27, no. 3, pp. 223-235, 1994.

[10] H. Al-Nofaie, "The attitudes of teachers and students towards using Arabic in EFL classrooms in Saudi public schools - a case study," Novitas-Royal Research on Youth and Language, vol. 4, no. 1, pp. 64-95, 2010.

[11] M. M. Alshammari, "The use of the mother tongue in Saudi EFL classrooms," Journal of International Educational Research, vol. 7, pp. 95-102, 2011.

[12] S. Krashen, Principles and Practice in Second Language Acquisition, Oxford: Pergamon, 1982.

[13] N. Chomsky, The Minimalist Program, Cambridge: MIT Press, 1995.

[14] B. B. Kachru, The Alchemy of English: The Spread, Functions and Models of Non-Native Englishes, Oxford: Pergamon, 1988.
[15] D. T. Al-Hajailan, Teaching English in Saudi Arabia, Riyadh: Aldar Alsawlatiah.

[16] D. Crystal, English as a Global Language, $3^{\text {rd }}$ ed. Cambridge: Cambridge University Press, 2003.

[17] T. Elyas and M. Picard, "Saudi Arabian educational history: Impacts on English language teaching," Education, Business and Society: Contemporary Middle Eastern Issues, vol. 3, no. 2, pp. 136-145, 2010.

[18] M. M. Rahman, ELT in Saudi Arabia: A Study of Learners' Needs Analysis, Germany: LAP Lambert Academic Publishing, 2011.

[19] M. A. Alam, S. M. Hussein, and B. A. Khan, "A study of the attitudes of students, teachers and parents towards English as a foreign language in Saudi Arabian public schools, Saudi Arabia," Ministry of Education, Educational Development, the General Directorate of Research \& Evaluation, 1988

[20] N. Bolotin, "Arabic speakers resetting of parameters," in Perspectives of Arabic Linguistics VIII, M. Eid, Ed. Amsterdam: John Benjamins, 1996, pp. 135-155.

[21] G. Rabab'ah, "Communication problems facing Arab learners of English," Journal of Language and Learning, vol. 3 no. 1, pp. 180-197, 2003.

[22] A. H. Sultan, "EFL teacher preparation program in Saudi Arabia: Trends and challenges," TESOL Quarterly, vol. 37, no. 2, 2003.

[23] H. A. Liton, "Developing EFL teaching and learning practices in Saudi colleges: A review," International Journal of Instruction, vol. 5, no. 2, pp. 129-152, 2012

[24] P. Nation, "The role of the first language in foreign language learning," Asian EFL Journal, vol. 5, no. 2, pp. 34-45, 2003.

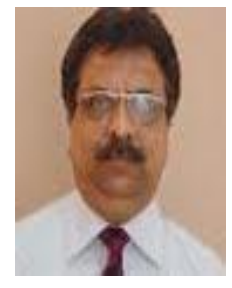

Mohammed Ilyas Ebrahim was born in India, in 1962. He is a senior academician who has a proven track record of strong academics, research, training and people management skills. He has an in-depth understanding of the technical, administrative and academic work environments, besides having acquired a rich expertise in teaching through proactive and remedial methods. He has worked as the principal in the ICFAI University and later as the director and dean in management institutions of high repute. During the last seven years, he has taken overseas assignments first as a professor in English language and literature at AlJabel Al Gharibi University, Libya, from 2009 to 2011, where he was also accredited with a jury membership, research studies, to assess and evaluate $\mathrm{PhD}$ and master's degree dissertations. Currently he is teaching in Sattam Abdul Aziz University, Saudi Arabia, since September 2011

Dr. Ilyas also has been teaching interdisciplinary subjects to both undergraduates and postgraduates. In addition, he was actively involved in research studies and has participated in numerous conferences and workshops and delivered technical papers. His research interests are in the field of teaching English language through technology (computer assisted language learning, CALL); ESP and ELT in a foreign language environment, need-assessment and evaluation and post war modern fiction.

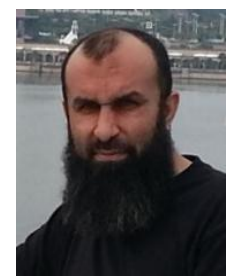

Naeem Afzal was born in Pakistan, in 1977 He got a MA degree in linguistics. He has been a lecturer at the Department of English Language and Literature, College of Science and Humanities, Prince Sattam bin Abdulaziz University, Saudi Arabia since 2007. He holds a master's degree in English language from Quaid-e-Azam University, Pakistan. He has an overall teaching experience of 14 years including Pakistan and Saudi Arabia. He is pursuing his $\mathrm{PhD}$ degree in applied linguistics at the Northern University of Malaysia. His current research interest includes discourse analysis and study of media discourses 